\title{
Beberapa Teknik Monitoring dan Evaluasi (MONEV)
}

\section{Elfindri*}

\section{*Andalas University}

\begin{abstract}
Abstrak
Artikel ini berupaya mengupas berbagai tahapan Monitoring dan evaluasi, yang sering dilakukan oleh berbagai peneliti. Namun banyak pula yang kurang paham, apa perbedaan dan kegunaannya. Dilanjutkan dengan memahami bagaimana data dimanfaatkan untuk kepentingan monev, ukuran yang ingin dipahami. Beberapa penelitian yang pernah penulis lakukan disarikan sebelum rangkuman hasil dari artikel ini.
\end{abstract}

\begin{abstract}
This paper is concern with the concept of monitoring and evaluation which is often used by researchers and practitioners. However, many of them also found some difficulties in interpreting and using it as a tools for achieving objectives. This paper also critically propose how data and evaluation is conducted. The final of this papaer is the previous research conducted to understand a various aspect of health and nutrition related behaviours.
\end{abstract}

Key Word: Monitoring and evaluation, health aspects

\section{Pendahuluan}

Setiap tahun, alangkah banyak program pembangunan yang direncanakan oleh pemerintah, termasuk bidang kesehatan. Baik kegiatan tersebut dibiayai melalui pemerintah pusat, pemerintah daerah propinsi, maupun kabupaten dan kota.
Kemudian dilaksanakan, baik oleh pemerintah melalui swa-kelola, maupun pihak ke-tiga. Saat bersamaan banyak pula pihakpihak yang melaksanakan program; apakah itu dari masyarakat, maupun kelompok Lembaga Swadaya Masyarakat (LSM).

Alamat Korespondesi: Elfindri, Andalas University, Padang Sumbar, email: elfindrifeua@yahoo.com.au 
Siapapun yang melaksanakan kegiatan akan selalu saja memerlukan perbaikan dari setiap proyek dan program yang dia jalankan. Masalahnya adalah bagaimana kita dapat melakukan perbaikan, tanpa diketahui apa yang tidak baik dari program sebelumnya. Berlaku dan sangat diperlukan bagi mereka yang juga terlibat dalam kajian kesehatan. Untuk itu keinginan untuk mengoreksi dan memperbaiki suatu program selalu saja memerlukan cara bagaimana secara akademik dilakukan yang memenuhi berbagai aspek. Mudah dilakukan dan mampu tenaga menjalankannya. Suatu perpaduan yang sering dituntun dalam melaksanakan suatu proyek. Salah satu kunci untuk menghasilkan perbaikan program yang baik adalah dari sisi "jam terbang". Hanya waktu yang menyebabkan kualitas dari hasil evaluasi menjadi semakin baik. Namun jam terbang tersebut dapat saja dipercepat masanya untuk menjadi evaluator yang baik dan handal. Maka untuk memenuhi aspek yang terakhir tadi, maka sebaiknya perlu memahami terminologi yang ada sehingga memudahkan kita untuk proses monitoring dan evaluasi.

\section{M@E Bagian Dari Good Coorporate Governance}

Sangat sering diperhatikan ketika pemerintah daerah menyusun program, banyak pula yang melanjutkan program yang sama. Dasarnya apa juga masih sangat sedikit informasi yang kami peroleh. Pada saat bersamaan banyak sekali penugasan untuk melakukan monitoring dan evaluation. Mereka melaksanakan tugas melihat bagaimana implementasi kegiatan. Bawasda, sebagai salah satu lembaga di daerah yang melakukan monitoring dan evaluasi sering melakukan hal ini. Ada yang melaksanakan secara step demi step sesuai dengan kaedah monitoring. Dan banyak juga yang dialami, mereka tidak mengerti apa itu evaluasi dan apa itu penyelidikan. Teman-teman di Badan Pengawas Daerah (Bawasda) sering melacak pelaksana kegiatan sebagai seseorang yang tersangka. Sehingga hasil proses evaluasi sering tidak memperoleh sasaran yang sesungguhnya. Faktor utama yang dirasakan berada pada cakupan yang dievaluasi dengan penguasaan yang dimiliki oleh evaluator yang terbatas. 
Habis melakukan evaluasi juga sering pula dilakukan rapat hasil evaluasi. Nah pada tahapan ini banyak sekali dari proses rapat yang lari dari substansi kegiatan. Sehingga apa yang dirapatkan dan apa indikator yang dinilai menjadi sangat tidak jelas dan fokus. Sehingga rapat-rapat yang dilakukan lebih sering membahas masalah yang spesifik dan detail, namun hilang kesempatan untuk menjadikan proses monitoring untuk koreksi kegiatan. Fenomena-fenomena itulah yang sering kami alami sebagai praktisi pendamping pemerintah dalam melaksanakan kegiatan-demi kegiatan yang dibuat.

Apakah itu terjadi pada pemerintahan daerah, ternyata di dunia kesehatan praktek pemanfaatan monitoring dan evaluasi sering tidak pada semestinya. Sebuah proses di perguruan tinggi kesehatan yang dapat dinyatakan telah melaksanakan 'good corporate governance' seharusnya melaksanakan monitoring dan evaluation secara berkesinambungan. Sehingga dari waktu ke waktu rencana kegiatan yang dibuat dan dibiayai semakin baik.
Definisi Dasar: Goals, indikator dan target

Banyak kita temukan terminologi dalam perencanaan dimana satu dengan lainnya memberikan makna yang berbeda. Agar lebih mudah dipahami, maka kita coba mendefinisikan masing-masing terminologi tersebut, sehingga tidak menjadi keliru.

Goal atau tujuan adalah sebuah tujuan akhir dari negara atau sebuah masyarakat untuk mencapai sebuah target tertentu. Misalnya 'membasmi kemiskinan', mengurangi kemiskinan, bebas buta huruf dan sebagainya. Dimana secara implisit dapat saja dikemukakan secara kualitatif, dan diartikulasikan secara kurang teknis. Sementara indikator adalah variable yang digunakan untuk mengukur tujuan. Misalnya kemajuan untuk mengukur pembasmian kemiskinan dapat dilakukan dengan melihat proporsi dari rumah tangga, katakan, yang berada di bawah garis kemiskinan. Sementara targets adalah tingkatan dimana negara atau sebuah masyarakat ingin untuk mencapainya. Dengan kata lain, target sering 
dengan rumusan yang kuantitatif sifatnya. Misalnya seluruh rumah tangga yang mampu memenuhi kebutuhan konsumsi di atas kebutuhan minimum dapat dicapai menjelang akhir tahun 2015.

\section{Apa itu monitoring hasil?}

Monitoring hasil dilakukan untuk tujuan untuk (a) memonitor trend dari luaran dalam kurun waktu, baik antar kelompok maupun antar tempat; (b) mengumpulkan informasi untuk mengumpulkan penyebab dari sebuah hasil atau keadaan dan (c) untuk memberikan umpan balik bagi pengambil kebijakan terhadap effectiveness dari sebuah program dan usaha-usaha untuk mengatasi sesuatu.

Pencapaian tujuan dalam proses pembangunan misalnya dapat dilihat dari pernyataan yang sudah disampaikan menjadi outcomes, misalnya mengurangi angka kematian bayi, meningkatkan angka buta aksara, mengurangi proporsi penduduk yang berada pada garis kemiskinan.

Dalam proses pembangunan jelas akan menghasilkan output fisik (misalnya jumlah jalan yang diaspal, jumlah sekolah, dan seterusnya). Sedangkan outcomes dapat dimengerti sebagai sebuah effek output yang dirasakan oleh rumah tangga. Misalnya dengan membangun sekolah, outcomesnya adalah berapa persen dari anak usia sekolah yang terdaftar. Dengan mengacu kepada terminologi $\mathrm{di}$ atas, maka monitoring hasil tentunya adalah melihat dari waktu ke waktu perubahan dari suatu set luaran dari proses pembangunan.

\section{Apa itu evaluasi dampak?}

Menurut definisi yang diberikan oleh Rubio dkk. (2000) "an impact evaluation assesses the changes in individuals' wellbeing that can be attributed to a particular program and policy. In other words, it determines the extend to which improvements in outcomes are due to a specific public actions".

Evaluasi dampak berbeda dengan minitoring. Pada proses monitoring, yang dipantau adalah perubahan dan penyimpangan dari ukuran-ukuran hasil pembangunan melalui intervensi dan cara tertentu, sedangkan dalam evaluasi dampak dilaksanakan untuk menemukenali masalah dan berbagai potensi faktor yang 
menjelaskan masalah tersebut. evaluasi dampak benar Dengan demikian proses dilaksanakan setelah selesainya monitoring langsung progam dilaksanakan. Untuk lebih menjadikannya sebagai bahan jelasnya dapat dilihat dalam tindakan koreksi sampai selesai Gambar 1. yang sederhana sekali pelaksanaan program, sementara di bawah ini.

Gambar 1. Bagan Alur Beda antara Monitoring dengan Evaluasi

Kegiatan evaluasi

@ (a)

Awal kegiatan

Akhir

Beberapa pertanyaan dapat diajukan sebagai bahan untuk melakukan evaluasi dampak antara lain:

(a) Apakah program telah mencapai tujuan?

(b) Dapatkan perubahan dari 'katakan' kemiskinan dapat dijelaskan dari pelaksanaan program atau dijelaskan oleh faktor diluar dari kebijakan, atau peranan dan dampak dari masing-masingnya berjalan secara serentak?

(c) Apakah dampak program sama atau berbeda antara satu kelompok dengan kelompok lainnya, antara satu daerah dengan daerah lainnya?
Kegiatan evaluasi

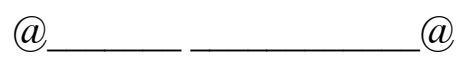

Awal

Akhir

(d) Adakah efek yang tidak diinginkan atau efek yang diinginkan terjadi sebagai akibat tercapainya tujuan yang ditetapkan?

(e) Sampai seberapa efektif suatu program dapat diterapkan dibandingkan dengan alternative program lainnya?

(f) Apakah program yang dibuat secara biaya paling baik untuk diterapkan dibandingkan dengan cara lainnya?

\section{Apa Beda Monitoring Hasil dengan Evaluasi Dampak?}

Perbedaan yang hakiki ada pada kapan dilakukan kegiatan evaluasi. Pada monitoring 
dilakukan selama pelaksanaan

diakhir kegiatan. Untuk segmen

program, dan pada evaluasi

kegiatan biasanya dilakukan tertentu lihatlah Tabel 1. sebagai pemandu.

Tabel 1.Perbedaan Antara Monitoring Hasil dengan Evaluasi Hasil

\begin{tabular}{l} 
Monitoring Hasil \\
\hline Tujuan \\
Untuk melihat perubahan, misalnya \\
perubahan proporsi rumah tangga \\
miskin dari waktu ke waktu
\end{tabular}

Evalusi Dampak

Menilai perubahan dari kemiskinan disebabkan oleh berbagai tindakan melalui kebijakan, dan mengevaluasi dampaknya terhadap antara komunitas, dan sekaligus perubahannya dalam rumah tangga

Data yang diperlukan

Nasional, propinsi, kabupaten, data

level rumah tangga yang

dikumpulkan antar waktu

Data rumah tangga yang dapat merepresentatifkan populasi setidaknya dalam dua rentang waktu yang berbeda, baik sebelum maupun setelah kebijakan dan program dijalankan. Data individu dalam rumah tangga dapat juga dijadikan sebagai sumber penjelasan dari penyebab perubahan dari kemiskinan.

\section{Metodology}

Membandingkan indicator dari waktu ke waktu

Membandingkan indicator yang sama sebelum adanya kebijakan dengan setelah adanya kebijakan; atau antara kelompok yang pernah memperoleh kebijakan dengan kelompok lain yang tidak menerima program sam sekali.

Sumber: Diadobsi dari Rubio, Prennushi dan Subbarao (2000: draft)

Goals atau Tujuan: Sebuah Konsensus

Goals atau tujuan perlu dinyatakan dalam setiap apa saja masalah yang ingin dipecahkan selama proses pembangunan. PBB biasanya memiliki goals atau tujuan-tujuan utama dan antara. Di bawah ini dapat dilihat bagaimana PBB mendefinsikan tujuan pembangunan. 
Untuk mencapai standar kehidupan ekonomi, maka goals adalah: Mengurangi penduduk miskin menjadi separo dari kondisi tahun dasar. Dan ini tercapai tahun 2015.

Dalam bidang pembangunan social, goals dinyatakan seperti pencapaian universal education menjelang tahun 2015. Menghapuskan perbedaan gender pada seluruh jenjang pendidikan sampai tahun 2015. Dan mengurangi 2/3 lebih rendah angka kematian bayi.

\begin{tabular}{lr}
\multicolumn{1}{c}{ Di bidang } & $\begin{array}{r}\text { lingkungan } \\
\text { dinyatakan } \\
\text { pembangunan }\end{array}$ \\
berwawasanan
\end{tabular}

lingkungan sebelum tahun 2010, untuk mengembalikan kembali kehilangan lingkungan.

\section{Indikator Apa Yang Akan dimonitor?}

Agar lebih mudah maka peneliti, atau pelaksana program sebaiknya mampu menemukan dan merumuskan apa indicator antara dan indicator akhir yang akan dimonitor nantinya dalam pelaksanaan kegiatan. Sering yang dilakukan dalam proses monitoring adalah antara guidelines dengan kenyataan, atau Dana Alokasi Satuan Kerja (DASK) dengan kenyataannya dan kalau dalam kontrak kerja DASK tidak dijelasakan secara terukur, maka proses monitoring bisa menjadi mengambang.

Dalam prakteknya, perlu dimonitor berbagai aspek yang terkait dengan berbagai indikator, baik indikator antara maupun indikator final dari suatu kegiatan. Sehingga seharusnya sebelum dilakukan monitoring, perlu digambarkan bagaimana indikator-indikator dapat diukur dari suatu goals yang telah ditetapkan oleh suatu pemerintah. Katakan contoh terkait dengan penanganan kemiskinan. Misalnya ketika pemberdayaan antara pria dan wanita adalah menjadi focus kebijakan, maka pengeluaran terhadap pendidikan dasar diangap sebagai faktor intermediate yang perlu dianalisisracy. Sementara literacy rate adalah menjadi outcomes yang perlu dinilai. 


\begin{tabular}{lcl}
\hline Goals & Indikator antara & Indikator akhir \\
\hline Mengurangi & Pengeluaran program & Maternal Mortality Rate \\
Angka kematian ibu & kesehatan ibu & \\
\hline Penurunan HIV & \% Jangkauan Program HIV & Penurunan Angka HIV \\
\hline
\end{tabular}

Contoh sederhana di atas dapat mempermudah kita dalam melakukan monitoring ataupun evaluasi. Dalam kaitan ini ketika kita mencoba memonitoring pelaksanaan program, maka kita perlu menggali informasi antara dana untuk penanggulangan kematian ibu melalui program perluasan kesehatan ibu dengan realisasi, kemudian membandingkannya dengan keharusan. Saat bersamaan datadata yang terkait dengan hasil dari program masih perlu pula dipastikan tersedia.
Data Untuk Memonitor Luaran Program?

Pekerjaan dalam menilai luaran program lebih luas ketimbang pekerjaan yang terkait dengan monitoring. Ketika monitoring dilakukan, besar kemungkinan data-data yang dimaksud belum tersedia oleh badan-badan yang menyediakannya. Sementara pada saat bersamaan data untuk menilai hasil pembangunan juga tidak mudah. Kata kuncinya adalah seberapa terintegrasinya pelaksanaan program dengan inisiatif menyediakan informasi. Jika data dan fakta lebih cepat tersedia, maka melacak luaran program lebih mudah dilakukan dan begitu sebaliknya. 
Tabel 2. Data, Sumber, Badan Penyedia, dan Frekuensi

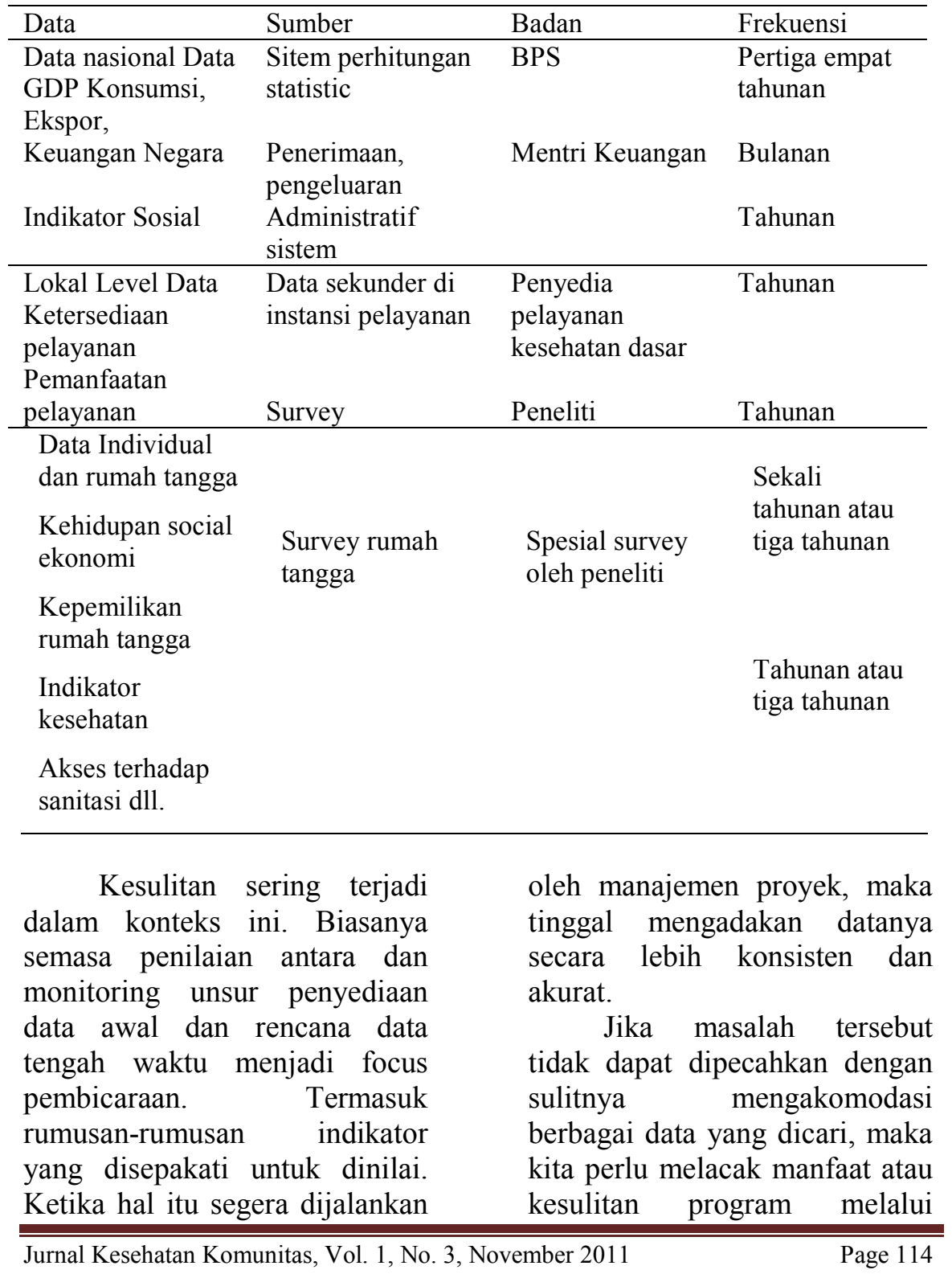


sample survey. Ini dapat dilakukan dengan melakukan case-control design, atau dengan metode lainnya seperti followup, atau retrospektif survey. Upaya upaya seperti ini nantinya akan memperoleh gambaran yang lebih komprehensif. Untuk lebih mudahnya, maka skala waktu evaluasi juga sangat tergantung kepada seberapa intens program dibuat, dan seberapa cepat evaluasi harus dilakukan.

Tabel 3. Program Intervensi dan Durasi Reviewnya

\begin{tabular}{lll}
\hline Interfensi & Outcomes & Timeframe \\
\hline $\begin{array}{l}\text { Program perluasan } \\
\text { lapangan kerja }\end{array}$ & Konsumsi, jam kerja & segera \\
\hline Intervensi Gizi & $\begin{array}{l}\text { Meningkatkan status gizi } \\
\text { balita }\end{array}$ & 4-6 tahun \\
\hline $\begin{array}{l}\text { Pengembangan masa } \\
\text { anak anak }\end{array}$ & $\begin{array}{l}\text { Peningkatan kesehatan, } \\
\text { gizi dan pengembangan } \\
\text { kognitif }\end{array}$ & $\begin{array}{l}\text { Menengah dan jangka } \\
\text { panjang }\end{array}$ \\
\hline
\end{tabular}

Sumber: Dalam Ravallion (2001)

Teknik-teknik Evaluasi Proyek

Bagian yang sangat penting adalah ketika kita ingin melakukan proses evaluasi dari suatu proyek yang terkait dengan pembangunan. Yang sering dipertanyakan adalah bagaimana caranya kita melakukan evaluasi itu? Kemudian tentunya cara evaluasi yang paling mudah dilaksanakan oleh pelaksana.

Dalam kaitan ini ada dua proses yang lazimnya perlu dilakukan oleh penyandang dana. Sebelum kegiatan evaluasi di lakukan si pemberi kegiatan, katakan dalam konteks ini Badan Perencanaan Daerah perlu terlebih dahulu menyusun TOR kegiatan. Dalam TOR berisi antara lain latar belakang kegiatan, tujuan kegiatan, methodology, dan seterusnya. Ketika menyusun methodology, si pemberi kegiatan perlu menyusun bagaimana cara mengevaluasi. Atas dasar tersebut, kemudian kegiatan dapat ditawarkan kepada si penerima pekerjaan. Tentunya dengan usulan-usulan yang paling logis untuk dilaksanakan. 
Penerima kegiatan sering juga mengalami kesulitan dalam menyusun bagaimana teknik evaluasi yang paling feasible. Mengingat kegiatan yang sifatnya kecil-kecilan sarat dengan ketersediaan tenaga dan uang untuk melaksanakannya. Namun langkah-langkah akademis harus tetap dipertahankan.

Untuk itu beberapa metode dalam mengumpulkan informasi dapat dilakukan dengan cara seperti berikut:

\section{a. Metode Case-Control}

Metode Case-control sering dinyatakan dalam literature sebagai metode control-designed. Prinsip dasar dari metode ini adalah dengan mengumpulkan berbagai set indikator dari sample yang memperoleh treatment atau memperoleh beneficiary atau manfaat. Kemudian dengan pemilihan pengamatan, sample ini kemudian dibandingkan indikatornya dengan pasangan sample yang karakternya adalah relatif sama.

Kekuatan dari metode ini adalah kita dapat membandingkan antara kelompok pengamatan yang menerima program dibandingkan dengan mereka yang tidak menerima. Kesulitannya adalah kalau sebuah program cakupannya luas, maka mereka yang tidak menerima program adalah sulit dilakukan. Dalam kaitan ini kesulitan dalam memperoleh pasangan sample yang benar benar sama tidaklah mudah dilakukan, karena banyak pertimbangan yang perlu dilakukan. Diantaranya adalah kesamaan karakter daerah, kesamaan relative latar belakang social-ekonomi. Ini dimaksudkan agar perbandingan nantinya memperoleh hasil isolasi faktor kebijakan semakin pasti dideteksi pengaruhnya. Tabel 4. memberikan contoh sederhana bagaimana metode case-kontrol dilakukan $^{1}$. 
Tabel 4. Metode Case dan Kontrol pada Berbagai Survey

\begin{tabular}{lll}
\hline \multicolumn{1}{c}{ Contoh Survey } & \multicolumn{1}{c}{ Case } & \multicolumn{1}{c}{ Kontrol } \\
\hline $\begin{array}{l}\text { Survey dampak } \\
\text { pelaksanaan program } \\
\text { Cuci Tangan Dengan } \\
\text { Sabun }\end{array}$ & $\begin{array}{l}\text { Rumah tangga yang } \\
\text { menerima program } \\
\text { kampanye cuci tangan } \\
\text { dengan sabun. }\end{array}$ & $\begin{array}{l}\text { Kontrol adalah rumah } \\
\text { tangga yang tidak } \\
\text { menerima program } \\
\text { dengan karakter yang } \\
\text { sama dengan kelompok } \\
\text { case. }\end{array}$ \\
\hline Survey Evaluasi & & $\begin{array}{l}\text { Rumah tangga yang } \\
\text { tidak pernah }\end{array}$ \\
Manfaat Program & pernah memperoleh & memperoleh kegiatan \\
Posyandu & aktivitas program & Posyandu \\
\hline posyandu & $\begin{array}{l}\text { Indikator kesehatan } \\
\text { dimana daerah yang } \\
\text { tenaga Kesehatan di } \\
\text { dusun terpencil }\end{array}$ & $\begin{array}{l}\text { Indikator kesehatan } \\
\text { daerah yang ditempatkan pernah }\end{array}$ \\
& tenaga kesehatan & memperoleh tenaga \\
& & kesehatan \\
\hline $\begin{array}{l}\text { Survey Manfaat } \\
\text { Bantuan Garam Oralit }\end{array}$ & $\begin{array}{l}\text { Rumah tangga yang } \\
\text { pernah menerima garam }\end{array}$ & $\begin{array}{l}\text { Rumah tangga yang } \\
\text { tidak menerima bantuan } \\
\text { garam oralit }\end{array}$ \\
\hline
\end{tabular}

\section{b. Metode Follow-Up}

Metode ke dua lazim juga digunakan oleh mereka yang sering menilai dampak dari suatu proyek. Metode follow-up lebih kepada metode yang melihat bagaimana perubahan yang terjadi dari mulai dilakukan proyek dan dibandingkan dengan waktuwaktu sesudah proyek dilaksanakan.

Metode follow-up nantinya dapat mengungkapkan bagaimana perubahan antar waktu objek yang memperoleh manfaat dari suatu program. Cara seperti ini sering dilakukan untuk menemukan berbagai persoalan yang terkait dengan managemen kegiatan, coverage kegiatan, pemanfaatan kegiatan, biaya kegiatan. Termasuk kajian kajian yang menilai seberapa tepat dan efektif dari suatu proyek dilaksanakan.

Metode follow-up lebih mudah dilakukan mengingat kita dapat mengenal calon sampel survei lebih mendalam mengingat informasinya dapat saja sekali, 
dua atau lebih. Sementara kesulitannya adalah pada aspek kegiatan itu sendiri. Jika kegiatannya dilakukan sudah jauh sebelum survei dilakukan, maka sering responden tidak ingat.

\section{c. Metode Retrospektif (Before-After)}

Metode retrospektif lebih kepada mencoba membandingkan aspek-aspek yang digali, kemudian dibandingkan dengan keadaan sebelum dilaksanakannya kegiatan. Misalnya melihat dampak dari suatu pelaksanaan proyek sebelum dan sesudah proyek dilaksanakan. Unsur-unsur yang perlu diperhatikan dalam mendesain dengan metoda ini adalah upayakan referensi waktu yang akan digunakan tidak jauh dari survey dilaksanakan. Jika semakin jauh, maka disanksikan responden akan mengingatnya.

\section{d. Metode Prospektif}

Metode prospektif berbeda dengan metode retrospektif. Pada metode prospektif unsur-unsur yang dikaji adalah bagaimana harapan ke depan dari aspek aspek yang ingin kita gali. Dapat saja kita ingin menggali opini masyarakat jika pemerintah ingin melakukan suatu kegiatan. Jadi unsur yang paling penting untuk digali adalah aspek kualitatif dari penerapan proyek dan perkiraanperkiraan yang akan diberikan oleh calon responden.

\section{Evaluasi Kualitatif dan Kuantitatif}

Kadangkala evaluasi yang memuaskan dihasilkan dari cara dan metoda evaluasi yang digunakan. Dalam perkembangannya, sebenarnya evaluasi dihasilkan dari dua teknik. Teknik pertama adalah cara evaluasi dengan kuantitatif. Kedua adalah cara evaluasi dengan kualitatif. Cara ketiga boleh dikatakan termasuk ke dalam kombinasi keduanya, kualitatif dan kuantitif.

Esensinya adalah pada cara evaluasi kualitatif sering digunakan untuk menemukan proses dan fenomena yang kita pelajari. Hasil evaluasi lebih banyak digunakan untuk mendalami seluk beluk proses, sebab dan konsekwensi yang dihasilkan. Melalui untaian kata dan deskripsi yang memberikan makna.

Sementara teknik kuantitatif mencoba menemukan besaran kuantitatif dari hubungan- 
hubungan relasional dari mampu memberikan gambaran fenomena yang dipelajari. apakah pertanyaan penelitian Dimulai dengan membangun telah mampu diungkap dengan model, kemudian model tersebut metoda yang digunakan.

Tabel 5. Perbedaan antar Metode kualitatif dengan kuantitatif dalam proses Evaluasi

\begin{tabular}{|c|c|c|}
\hline & Kuantitatif & Kualitatif \\
\hline Tujuan & $\begin{array}{l}\text { Untuk mengukur } \\
\text { hubungan yang terjadi } \\
\text { antara satu variabel } \\
\text { dengan variabel lain }\end{array}$ & $\begin{array}{l}\text { Untuk menemukan proses, } \\
\text { tingkah laku, kondisi dan } \\
\text { persepsi dari individu dan } \\
\text { kelompok }\end{array}$ \\
\hline $\begin{array}{l}\text { Pengumpulan } \\
\text { data dan } \\
\text { instrumen }\end{array}$ & $\begin{array}{l}\text { Terstruktur, format, } \\
\text { didesain lebih dulu dan } \\
\text { dipastikan }\end{array}$ & $\begin{array}{l}\text { Mendalam, dengan in-debth, } \\
\text { open-ended questionnaire } \\
\text { Langsung mengobservasinya } \\
\text { Dokumen tertulis, diary, dsb. }\end{array}$ \\
\hline $\begin{array}{l}\text { Sampling } \\
\text { Metodology } \\
\text { analisis }\end{array}$ & $\begin{array}{l}\text { Probability sampling } \\
\text { Lebih dominant alat } \\
\text { statistic, mulai dari yang } \\
\text { paling sederhana sampai } \\
\text { advance }\end{array}$ & $\begin{array}{l}\text { Purposive sampling } \\
\text { Triangulasi (mengecek } \\
\text { contenaran dan cross- } \\
\text { checking) } \\
\text { Systematic content analysis } \\
\text { Mengenarilasi fenomena dari } \\
\text { hasil mendalam beberapa } \\
\text { pengamatan }\end{array}$ \\
\hline
\end{tabular}

Sumber: Dalam Elfindri dkk (2011)

Sejauh manakah validitas evaluasi tergantung dari data yang dikumpulkan. Sehingga hasil analisis sangat ditentukan kepada sejauh mana kombinasi kualitatif dan kuantitatif data yang diperoleh. Secara umum, kualitatif data dikumpulkan untuk hal-hal yang spesifik, seperti sikap masyarakat, pilihan dan preferensi. Sebaliknya metode kuantitatif sangat bersandar kepada sistem random yang diadopsi, yang dilengkapi dengan instrumen yang memadai

Dari uraian tersebut, dapat dimengerti bahwa teknik kuantitatif dapat dikombinasikan dengan teknik kualitatif bilamana memerlukan pemahaman yang lebih komprehensif sewaktu evaluasi dilakukan. Tabel 5 di atas merupakan kutipan kami terhadap dokumen yang 
dihasilkan oleh Baker (1999) dimana dapat memberikan pemahaman yang lebih maju terhadap pentingnya diketahui beda antara kualitatif dan kuantitatif.

\section{Kajian Evaluasi Antar Negara}

Berikut ini disarikan bagaimana penelitian terdahulu telah dilakukan di berbagai negara, termasuk dengan teknik evaluasi yang juga bervariasi.
Gambaran singkat yang dapat kita temukan bahwa ternyata kebanyakan penelitian terdahulu banyak yang lebih pesimis menemukan, dalam arti lebih banyak kegagalan ketimbang keberhasilan dari program yang dipilih. Dalam konteks biaya, kajian telah memakan berkisar US\$ 300.000-500.000. per jenis evaluasi dampak. Rangkuman dapat dilihat pada Tabel 6 .

Tabel 6. Beberapa Contoh Kajian evaluasi Antar Negara dengan Teknik yang bervariasi

\begin{tabular}{|c|c|c|c|}
\hline Penelitian/Sektor & Metode & Hasil & Kebijakan \\
\hline $\begin{array}{l}\text { Peningkatan } \\
\text { kualitas dan } \\
\text { kuantitas } \\
\text { pendidikan dasar } \\
\text { di Ghana } \\
\text { Evaluasi } \\
\text { Kebijakan tahun } \\
\text { 1986 dibidang } \\
\text { pendidikan dasar }\end{array}$ & $\begin{array}{l}170 \text { area dipilih } \\
\text { secara random, } \\
\text { ekonometrika, } \\
\text { enrolment dan } \\
\text { learning } \\
\text { outcomes } \\
\text { sebagai } \\
\text { independen } \\
\text { variable }\end{array}$ & $\begin{array}{l}\text { Penelitian ini } \\
\text { menemukan dampak } \\
\text { dari kebijakan } \\
\text { pendidikan dasar } \\
\text { secara signifikan, } \\
\text { walaupun juga } \\
\text { ditemukan gap } \\
\text { pencapaian kualitas }\end{array}$ & $\begin{array}{l}\text { Memperkuat } \\
\text { hardware } \\
\text { dibandingkan } \\
\text { software di bidang } \\
\text { pendidikan dasar }\end{array}$ \\
\hline $\begin{array}{l}\text { Pencapaian } \\
\text { MDG di } \\
\text { Bangladesh, } \\
\text { periode 1980- } \\
1990\end{array}$ & $\begin{array}{l}\text { Data set DHS } \\
\text { survei, dengan } \\
\text { menggunakan } \\
\text { multivariat } \\
\text { kesehatan dan } \\
\text { gizi sebagai } \\
\text { dependent. }\end{array}$ & $\begin{array}{l}\text { Kemajuan ekonomi } \\
\text { telah berkontribusi } \\
\text { terhadap penurunan } \\
32,9 \% \text { kematian } \\
\text { bayi, namun hanya } \\
16 \% \text { penurunan } \\
\text { kelahiran }\end{array}$ & $\begin{array}{l}\text { Kebijakan } \\
\text { peningkatan } \\
\text { kapasitas lokal } \\
\text { TBA telah } \\
\text { berhasil } \\
\text { mengurangi angka } \\
\text { kematian bayi, } \\
\text { yang disebabkan } \\
\text { oleh tetanus. }\end{array}$ \\
\hline
\end{tabular}


Lanjutan table 6.

\begin{tabular}{|c|c|c|c|}
\hline Penelitian/Sektor & Metode & Hasil & Kebijakan \\
\hline $\begin{array}{lr}\text { Program } & \text { Gizi } \\
\text { Terintegrasi } & \text { di } \\
\text { Bangladesh, } & 1980- \\
1990 \text { an } & \end{array}$ & $\begin{array}{l}\text { Base line, mid, } \\
\text { and final project, } \\
\text { follow-up. Dan } \\
\text { membandingkan } \\
\text { antara area } \\
\text { kebijakan } \\
\text { dengan tanpa } \\
\text { kebijakan }\end{array}$ & $\begin{array}{l}\text { Program } \\
\text { pemberian } \\
\text { makanan tidak } \\
\text { memperlihatkan } \\
\text { dampak yang } \\
\text { berarti terhadap } \\
\text { perbaikan gizi } \\
\text { anak }\end{array}$ & $\begin{array}{lr}\text { Pesan kampanye } \\
\text { gizi } & \text { perlu } \\
\text { diperbaiki } & \text { pada } \\
\text { daerah } & \text { target } \\
\text { group. } & \end{array}$ \\
\hline $\begin{array}{l}\text { Ekstensifikasi } \\
\text { Pertanian di Kenya, } \\
1980 \text { an }\end{array}$ & $\begin{array}{lr}\text { Training } & \text { dan } \\
\text { Visit } & (\mathrm{T} \& \mathrm{~V}) \\
\text { dikenalkan }\end{array}$ & $\begin{array}{l}\text { Program } \\
\text { peningkatan } \\
\text { kapasitas petani, } \\
\text { dengan } \\
\text { melakukan } \\
\text { survey terhadap } \\
285 \text { rumahtangga }\end{array}$ & $\begin{array}{l}\text { Dampak } \\
\text { program tidak } \\
\text { terlalu kelihatan } \\
\text { alias sangat kecil } \\
\text { terhadap praktek } \\
\text { pertanian. }\end{array}$ \\
\hline $\begin{array}{ll}\text { Proyek Irigasi } & \text { di } \\
\text { Pakistan, } 1994 & \end{array}$ & $\begin{array}{l}391 \text { Treatment } \\
\text { dibandingkan } \\
100 \text { petani non } \\
\text { interventian }\end{array}$ & \begin{tabular}{l}
\multicolumn{2}{l}{ Pelaksanaan } \\
program irigasi \\
ternyata telah \\
berdampak pada \\
partisipasi fihak \\
swasta
\end{tabular} & \\
\hline $\begin{array}{lr}\text { Program } & \text { Kredit } \\
\text { Pedesaan } & \text { di } \\
\text { Pillippines } & \end{array}$ & $\begin{array}{l}738 \text { borrowers, } \\
20 \% \\
\text { beneficiaries. } \\
\text { Before and after } \\
\text { model dalam } \\
\text { menemukan } \\
\text { dampak }\end{array}$ & $\begin{array}{l}\text { Produksi dan } \\
\text { produktifitas } \\
\text { petani } \\
\text { meningkat. } \\
\text { Namun tidak } \\
\text { berkembang dari } \\
\text { sisi jenis } \\
\text { tanaman. }\end{array}$ & \\
\hline
\end{tabular}

Diringkaskan dari Ravallion, 2001.

Beberapa catatan dapat bervariasi antara satu tempat dilihat bahwa dalam mereview dengan lainnya. Kemudian juga keberhasilan program memerlukan baseline data yang baik. Model review juga dari kajian yang menggunakan estimasi, laporan menujukkan terbatas narasi temuan, sebaliknya 
dengan pendekatan pendalaman kecenderungan hasil lebih mendalam, namun pembuktian dari hasil tidak selalu memuaskan.

\section{Penelitian Lapangan Yang Powerfull}

Sekalipun dalam kurun waktu 20 tahun terakhir sudah banyak kemajuan metoda kuantitatif, para ekonom telah dijebak dengan penelitian kausalitas. Penelitian kausalitas memang akan memperoleh besaran magnitude terhadap fenomena yang dipelajari. Namun dalam realitasnya banyak diantara keunikan- kunikan yang terjadi belum mampu kita mengungkapkan jawabannya. Lebih khusus, jika kita ingin memperoleh pendalaman terhadap pertanyaan penelitian kita Dengan arti kata, agar sebuah penelitian 'berbunyi' dan mampu menjawab pertanyaan "Why", penelitian lapangan adalah salah satu ruang gerak untuk kita mampu mempelajari rahasia dibalik pertanyaan yang diajukan. Bagian yang singkat mengakhiri bab ini akan menuangkan berbagai pemahaman yang penulis peroleh dari proses penelitian lapangan, dan manfaat dari penelitian lapangan dalam mengungkap rahasia yang ada di balik hipotesa yang kita ajukan.

\section{Kenali Dulu Data Sekunder}

Sekalipun kita ingin akhirnya menggunakan penelitian lapangan, namun peneliti ekonom misalnya memerlukan upaya untuk menemukan data sekunder yang tersedia. Data sekunder yang tersedia sebenarnya sangat kaya, baik yang sudah dipublikasi oleh BPS atau lembaga resmi lainnya, maupun data yang tersedia dalam bentuk raw, atau data-data yang belum terolah. Jika data sekunder tersedia, maka manfaatkan seoptimal mungkin data tersebut untuk menjawab pertanyaan penelitian yang kita ajukan.

Aspek apa yang harus kita kenali?. Diantaranya adalah instrumen apa yang digunakan oleh instansi yang memiliki dan menghasilkan data. Dan apakah data yang dihasilkan memiliki reabilitas dan representatifness. Hal ini untuk menjaga agar upaya kita memahami jawaban akan persoalan menjadi lebih bermakna. Dengan tahap ini, kita perlu berdiskusi lebih intent dengan kawan kawan yang merancang pengadaan data tersebut. Akan tapi jika data sekunder tersedia dalam kualitas 
yang dipertanyakan, maka menggunakan data sekunder akan berbahaya dalam upaya mencari jawaban.

Diantara data data sekunder yang sangat baik dan tersedia adalah seperti data publikasi BPS, yang dioleh melalui data Susenas 1976-2005, Sensus Pertanian (1983,1993 dan 2003), Sensus Penduduk, 1980, 1990, 2000; Supas 1985, 1995 dan 2005; Sensus Ekonomi, 1996 dan 2006. Termasuk data yang dipulbilkasi oleh BI, dan berguna untuk kajian kajian yang terkait dengan ekonomi moneter. Data data dasar mudah dipesan, dan sediakan biaya transfers sesuai dengan variable yang kita perlukan. Dengan singkat saya ingin menyatakan bahwa sebuah penelitian yang objektif adalah jika data yang ada dioptimalkan. Dan ketika kita tidak lengkap dilengkapi dengan data lapangan. Alias, jika data yang ada kita benar benar tidak mampu menjawab pertanyaan penelitian, maka berikutnya perlu upaya melengkapi dari data yang ada melalui penelitian lapangan.

\section{Apa Keuntungan Data Lapangan?}

Keuntungan data lapangan adalah si peneliti, jika melalui prosesnya, akan mengenal secara langsung gambaran daerah dan objek penelitian. Karena hasil observasi yang dilakukan sangat berguna sebagai dasar untuk melakukan "narasi dan interpresi" terhadap suatu fenomena. Jika peneliti tidak ikut dalam proses pengumpulan data lapangan, maka akan terjadi pendangkalan dari pemaknaan proses menjawab pertanyaan penelitian. Saya menganggap kenapa para ilmuan yang sering menggunakan data lapangan relatif lebih mudah mengungkap dan menarasikan persoalan persoalan yang dia lihat. Dan ini salah satu jawaban kenapa peneliti lapangan lebih produktif dalam menghasilkan karya karyanya ketimbang peneliti di "belakang meja".

Yang lebih menjanjikan adalah bahwa penelitian lapangan mampu memberikan bekal kepada kita untuk menelusuri un-known relationships, sementara known relationship sepertinya tidak terlalu menarik lagi untuk ditelusuri. 
Titik Kritis Penelitian

\section{Lapangan}

Jika benar para peneliti memerlukan data lapangan, titik kritis yang perlu dilalui secara seksama adalah:

a. Kenali Framework Penelitian. Kerangka penelitian kita akan memudahkan kita dalam merangkum aspek aspek apa saja yang akan kita gali dari objek penelitian, termasuk informasi dan data yang diperoleh melalui responden, key informan, observasi fisik dan non fisik terhadap objek penelitian.Jika peneliti paham yang akan dicari, maka akan memudahkan dalam menyusun instrumen.

b. Mempersiapkan instrumen. Instrumen adalah alat pengumpul data, dan bisanya melalui kuesioner. Ruang lingkup kuesioner perlu sedemikian rupa disusun, sehingga informasi yang kita perlukan lengkap diperoleh. Cara yang paling mudah untuk membuat instrumen adalah dengan mempedomani instrumen sebelumnya yang pernah disusun oleh lembaga seperti BPS. Instrumen kemudian dilengkapi dengan pedoman wawancara. Dimana pedoman wawancara berguna dan sebagai alat definsi operasional standar yang digunakan oleh peneliti.

c. Coatching dan ujicoba. Coatching adalah dimaksudkan agar seluruh anggota Tim memahami secara komprehensif maksud pengumpulan data. Dan segala data yang kit perlukan dikumpulkan dengan teknik dan cara yang sudah diteapkan dalam desain penelitian. Para pengumpul data memerlukan sifat "keingintahuan" yang lebih tinggi. Mengingat jawaban dari pertanyaan yang "sebenarnya" dari objek peneliti tidak selalu mudah diperoleh. Disamping itu ujicoba perlu mengingat desain penelitian menjadi mudah dan konsistensi waktu, pertanyaan, dan cakupan dapat diperoleh secara optimal.

d. Pengaturan sampling. Sampling yang digunakan disesuaikan dengan tujuan kita. Kita dapat saja menggunakan sampling acak, bertahap, campuran, maupun non sampling. Namun sampling apapun yang digunakan harus menjaga agar data yang diperoleh probabilitasnya sama bagi seluruh unit populasi yang kita susun. Jika sampling yang kita susun menurut semau peneliti alias non scientific 
approach, maka hal ini akan mempengaruhi generalisasi dari temuan kita.

e. Berupaya Menggali Informasi: Mempertajam Jawaban Siapa, Bagaimana, Kenapa, dan seterusnya. Lakukan pencatatan harian terhadap fenomena yang anda temukan di lapangan. Catatan harian bahkan sangat berguna untuk menambah narasi dan interpretasi kita.

\section{Apa Manfaat Penelitian Lapangan Untuk Hipotesis Saya?}

Salah satu upaya saya membuktikan bahwa sekalipun rumah tangga memiliki constraint resources, berupa pendidikan, namun antar tempat peranannya bisa berbeda. Dan perbedaan itu berasal dari faktor tingkah laku. Dan tingkah laku dapat diperbaiki dari semakin intensifnya implementasi program pemerintah.

Model 1 di atas saya buktikan melalui formulasi persamaan sebagai berikut:

Ln Supp Feeding $=$ ao + a1EDUC $+\mathrm{a} 2 \mathrm{PROG}+\mathrm{a} 3$ EDUCXPROG + Et.
Elfindri (1995) mengajukan hipotesis bahwa nilai a3 $<0$, berarti program kesehatan sudah tepat. Namun apakah tanda a3<0 signifikan atau tidak memerlukan penelitian pendalaman, kenapa bisa signifikan, kenapa dia bisa saja tidak signifikan. Jika kita memainkan ekonometri, maka yang mampu kita temukan adalah magnitude besaran dari koefisien dari a3. Kekuatan kita menggali kenapa dia signifikan dan tidak signifikan dilakukan melalu observasi dan penelitian pendalaman.

Dengan penelitian pendalaman, maka hasil study saya mengungkap bahwa peranan pendidikan sekalipun rendah akan dapat meningkatkan kualitas manusia dini di daerah penelitian sampling saya. Saya menemukan adanya perbedaan interaksi antara ibu di satu daerah dengan ibu di daerah lain.

Model 2. kenapa daerah dimana akses pipe water tinggi mengalami diarhoea balita yang juga tinggi? Paradox tentunya.

Ln Diarrhoea $=\mathrm{a} 0+\mathrm{a} 1$ Pipe $+\mathrm{a} 2$

Educ + a3 Bahvior + a. 4

PipeBehavior+ et. 
Hipotesis Schultz (dalam Elfindri, 2002) untuk koefisien a4 adalah negatif, dan saya temukan justru rumah tangga yang punya pipe water kemungkinan diarrhoea anak tinggi. Dan penelitian participant observation mampu menjelaskan kenapa rumah tangga pipe water probabilitas anak menderita diarhoeal diseses tinggi dibandingkan dengan anak yang tinggal pada rumah tangga lain, dan tidak memperoleh piped water. Pada rumah tangga yang terakhir diperoleh gambaran mereka memiliki tingkah laku yang kondusif terhadap kebersihan yang terkait dengan proses pemberian makanan. Sementara pada rumah tangga pipe water, terdapat proses yang menyebabkan air yang digunakan terkontaminasi dengan tempat penyimpanan di rumah. Proses kontaminasi, berikutnya menyebabkan peralatan yang digunakan juga memiliki resiko dihinggapi germ, dan seterusnya dapat menjelaskan terjadinya proses diarhoea.

Penelitian Lapangan Pelengkap

Survey yang dilaksanakan dengan cara yang sudah dipersiapkan secara objektif sebaiknya dilengkapi dengan teknik teknik lapangan lain, sesuai dengan urgensi penelitian. Beberapa diantaranya adalah melalui indebt interview, focus group discussion, participant observation, penelusuran dokumen, dan sebagainya.

Penelitian dengan gaya murni social science seperti ini menjadi sangat kaya manfaatnya bagi mereka yang memiliki basic ekonomi. Mengingat selama ini, kebanyakan dari anak anak mahasiswa ekonomi menghasilkan proses riset akhirnya secara "by pass", dengan pengalaman yang sangat minimum. Saya merasakan anak anak yang saya bimbing yang menggunakan penelitian lapangan relatif lebih matang dan memiliki pengetahuan yang semakin luas dibidangnya ketimbang yang menggunakan alat test dengan data yang sering diragukan.

Kata kunci dalam penelitian lapangan pelengkap adalah, bahwa kita berupaya untuk mampu menjelasakan kenapa magnitude dari hubungan hubungan yang kita lihat? Sementara pada desk research penjelasan kenapa masih belum mampu kita jawab. Selain dari itu 
penelitian lapangan, jika si peneliti ikut melaksanakan, akan mengurangi penjelasan kemungkinan, melainkan secara lebih persis menemukan jawaban terhadap persoalan yang dihadapi.

\section{Kesimpulan dan Rangkuman}

Dari gambaran singkat di atas, dapatlah dimengerti bahwa kegiatan monitoring dan evaluasi dapat dilakukan oleh siapa saja dan untuk program pembangunan apa saja. Tinggal bagaimana menggunakan metoda yang praktis dan mudah, namun tidak meninggalkan kaedah-kaedah dari objektivitas kegiatan evlausi dan monitoring.

Kata kunci dari metode yang digunakan adalah kesiapan dari metode, instrument, dan kemampuan dalam menggali persoalan, kemudian mengkaitkannya dengan menemukan akar masalah. Kemudian akar masalah adalah solusi yang dapat dikemukakan sebagai dasar untuk menghasilkan monitoring, sekaligus dapat dijadikan sebagai dasar untuk merumuskan perbaikan program ke depan.

Bagian ini juga mengajak agar kiranya mereka yang kuat akan kuantitatif melengkapi hasil evaluasinya dengan penelitian pendalaman, sesuai dengan yang didiskusikan pada bagian sebelumnya. Metoda kombinasi ini dalam me-review akan memberikan kekuatan dan kedalaman analisis.

\section{Daftar Pustaka}

Carvalho, Soniya and Howard White (1997) "Combining the quantitative and qualitative approach to poverty measurement and analysis: the practice and potential: The World Bank Technical Paper, No. 366. The World Bank Washington.

Elfindri (1995) The differentials in child nutritional outcomes in rural West Sumatra, unpublished Ph.D. thesis, Flinders University, Australia.
Elfindri (2002) "Ekonomi Layanan Kesehatan”, Andalas University Press.

Elfindri dkk (2007) "Strategi Sukses Membangun Daerah", Gorga Media.
Elfindri dkk (2011) "Metode Penelitian Kesehatan", Baduose Media


Ravalion, Martin (2001) The

Bank Economic Review, Vol mystery of the vanishing 15, No.1. 115-140. benefits: an introduction to impact evaluation", The world

1 . Tabel ini didasarkan pada praktek-praktek survey evaluasi yang pernah penulis lakukan, melalui survey pilot proyek kegiatan-kegiatan intervensi yang pernah dilakukan di Sumatra Barat.

${ }^{2}$ Kegiatan evaluasi skala besar sering dilakukan oleh badan-badan yang sering melaksanakan kegiatan serupa. Seperti proyek-proyek yang dibiayai oleh Bank Dunia, Uniceff, dan Dana Kependudukan, maka kegiatan survey sering dilakukan dengan melibatkan sample survey yang cukup luas cakupannya dengan jumlah pengamatan yang juga besar. Ini dapat dimengerti untuk menjadikan hasil evaluasi jauh lebih komprehensif. Cara seperti ini biasanya memenuhi kaedah-kaedah kajian yang lengkap. Namun pada proyek-proyek yang relative mini, dengan kata lain dilaksanakan pada wilayah dan cakupannya terbatas, maka dapat saja sample survey dilakukan, dengan disertai dengan metode Rapid Rural Apprisal (RRA). Kalau sekiranya data dan informasi yang diperoleh lebih mengarah ke pada jawaban kualitatif, maka metode in-debt interview, Focus Group Discussion, dan participant observation adalah sering digunakan.

3. Tabel ini didasarkan pada praktek-praktek survey evaluasi yang pernah penulis lakukan, melalui survey pilot proyek kegiatan-kegiatan intervensi yang pernah dilakukan di Sumatra Barat.

4. Studi kami pada tahun 1992 mencoba mengevaluasi dampak pembangunan fasilitas jamban keluarga di pedesaan Sumatra Barat, tepatnya di kecamatan Bonjol, Pasaman. Data yang dipeoleh adalah dari kuaesioner tentang pemanfaatan dari fasilitas yang dibangun. Namun, karena daerah Bonjol adalah salah satu kecamatan di mana angka kekurangan gizi relative tinggi, maka data kualitatif sangat diperlukan. Diantara data kualitatif yang penulis kumpulkan adalah bagaimana penggunaan dari fasilitas jamban keluarga, bagaimana proses air minum di bawa dari public pipe water dibawa ke rumah yang mudah saja proses kontaminasi terjadi. Hasil analisis dengan menggabungkan data kualitatif dengan data kuantitatif sangat besar peranannya dalam mengambil kesimpulan. Lihat Elfindri (2005) "The Differentials in child nutritional outcomes in rural West Sumatra Indonesia, Unpublished Ph.D. Thesis, Flinders University Australia. 